\title{
Partisipasi Masyarakat Dalam Pembangunan di Desa Kuala Sempang Kecamatan Seri Kuala Lobam Kabupaten Bintan Tahun 2014
}

\author{
Kustiawan' ${ }^{1}$ dan Kohen Sofi ${ }^{2}$ \\ ${ }^{1}$ Jurusan Ilmu Pemerintahan Fakultas Ilmu Sosial dan Ilmu Politik \\ UMRAH Tanjung Pinang Indonesia \\ ${ }^{2}$ Mahasiswa Ilmu Pemerintahan Fakultas Ilmu Sosial dan Ilmu Politik \\ UMRAH Tanjung Pinang Indonesia \\ anto2002sg@yahoo.com
}

\begin{abstract}
By paying attention to the experience of regional autonomy in the past that embraces the principle of real autonomy and responsible with an emphasis on more autonomy is the obligation of the right, then in this law granting autonomy to local authority districts and areas of the city based on the principles of decentralization alone in the form of broad autonomy, real and responsible. With the implementation of the research in the village of Kuala Sempang District of Kuala Lobam Series Bintan regency is expected to provide an overview of how the process of public participation in the implementation of regional development so that the concept of participatory development that has been applied can be dosed and can be used as a reference in subsequent studies related to substances.From the research that has been carried out, can be drawn that the application of community participation in development in the village of Kuala Sempang District of Kuala Lobam Series Bintan regency. If the view of the indicators of community participation in the development of community participation in the form of an idea or ideas, participation in the form of materials, participation in the form of labor and community participation in the form of utilization of development. The contribution of participation in the form of energy is the largest in any development process implemented. Participation in the form of utilization of development for the community is when development is aimed at the welfare of rural communities, the people will really take advantage and menajaga development that has been implemented by the village government to the people in the village of Kuala Sempang. Although in the process encountered a small obstacles but does not reduce the spirit of mutual aid societies to build their village.
\end{abstract}

Keywords: community particiation, rural development

\begin{abstract}
Abstrak
Dengan memperhatikan pengalaman otonomi daerah di masa lalu yang mencakup prinsip otonomi riil dan bertanggung jawab dengan penekanan pada otonomi lebih adalah kewajiban hak, maka dalam undang-undang ini memberikan otonomi kepada pemerintah daerah kabupaten dan wilayah berbasis kota. pada prinsip desentralisasi sendiri dalam bentuk otonomi luas, nyata dan bertanggung jawab. Dengan dilaksanakannya penelitian di Desa Kuala Sempang Kecamatan Kuala Lobam Kabupaten Bintan diharapkan dapat memberikan gambaran umum bagaimana proses partisipasi masyarakat dalam pelaksanaan pembangunan daerah sehingga konsep pembangunan partisipatif yang telah diterapkan dapat Dosis dan bisa dijadikan referensi dalam penelitian lanjutan terkait zat. Dari penelitian yang telah dilakukan, dapat ditarik bahwa penerapan partisipasi masyarakat dalam pembangunan di Desa Kuala Sempang Kecamatan Kuala Lobam Kabupaten Bintan. Jika dilihat dari indikator partisipasi masyarakat dalam pengembangan partisipasi masyarakat dalam bentuk ide atau gagasan, partisipasi dalam bentuk materi, partisipasi dalam bentuk persalinan dan partisipasi masyarakat dalam bentuk pemanfaatan pembangunan. Kontribusi partisipasi dalam bentuk energi adalah yang terbesar dalam proses pembangunan yang diimplementasikan. Partisipasi dalam bentuk pemanfaatan pembangunan bagi masyarakat adalah ketika pembangunan ditujukan untuk kesejahteraan masyarakat pedesaan, masyarakat akan benar-benar memanfaatkan dan menajaga pembangunan yang telah dilaksanakan oleh pemerintah desa kepada masyarakat di desa Kuala Sempang. Meski dalam prosesnya mengalami hambatan kecil namun tidak mengurangi semangat gotong royong untuk membangun desanya.
\end{abstract}

Kata Kunci: partisipasi masyarakat, pembangunan pedesaan 


\section{PENDAHULUAN}

Setiap negara dalam menjalankan roda pemerintahannya selalu berpedoman pada kebijakan politik yang dianut negara itu sehingga prosedur birokrasi yang ditempuh juga mengacu kepada paradigma sistem politik yang dianutnya. Mengingat besarnya penguasaan pemerintah pusat kepada pemerintah darah dengan dalih pencegahan separatism, namun kenyataanya sekaligus di muka, maka dibentuklah pengganti Undang-Undang No. 5 Tahun 1974 tentang Pokok-pokok Pemerintahan di Daerah yaitu menjadi Undang-Undang No. 22 Tahun 1999 tentang Pemerintah Daerah dan Undang-Undang No. 25 Tahun 1999 tentang Perimbangan Keuangan antara Pemerintah Pusat dan Pemerintah Daerah yang kemudian diubah lagi menjadi Undang-Undang No. 32 Tahun 2004 tentang Pemerintah Daerah, paradigma birokrasi di Indonesia mengalami perubahan dari paradigma pemerintahan yang sentralistik ke arah desentralistik (dalam Inu Kencana 2011:193).

Dengan memperhatikan pengalaman penyelenggaraan otonomi daerah pada masa lampau yang menganut prinsip otonomi yang nyata dan bertanggungjawab dengan penekanan pada otonomi yang lebih merupakan kewajiban dari pada hak, maka dalam undang-undang ini pemberian kewenangan otonomi kepada daerah kabupaten dan daerah kota didasarkan kepada asas desentralisasi saja dalam wujud otonomi yang luas, nyata dan bertanggungjawab.

Pengertian otonomi nyata adalah keleluasaan daerah untuk menyelenggarakan kewenangan pemerintahan dibidang tertentu yang secara nyata ada dan diperlukan serta tumbuh, hidup, dan berkembang di daerah.Yang dimaksud dengan otonomi yang bertanggungjawab adalah berupa perwujudan pertanggungjawaban sebagai konsekuensi pemberian hak dan kewenangan kepada daerah dalam wujud tugas dan kewajiban yang harus dipikul oleh daerah dalam mencapai tujuan.

Pada kenyataannya desentralisasi diminati banyak orang karena didalamnya terkandung semangat demokrasi, yang ujungnya dapat meningkatkan partisipasi masyarakat dalam penyelenggaraan pemerintahan termasuk didalamnya penyelenggaraan pembangunan Arif (dalam A. Umar Mustari, 2011:1).Dengan demikian, harapan masyarakat untuk mencapai pembangunan dalam rangka perubahan kondisi dari suata realita ke realita secara keseluruhan menjadi lebih baik, akan tercapai melalui konsep yang lebih mendekatkan pemerintah dengan rakyatnya, sebagaimana falsafah yang terkandung didalam otonomi daerah tersebut, yaitu partisipasi masyarakat.

Partisipasi merupakan proses pemberdayaan masyarakat, sehingga mampu menyelesaikan sendiri masalah yang mereka hadapi, melalui kemitraan, transparansi, 
kesetaraan, dan tanggungjawab.Di Indonesia, landasan hukum pelaksanaan partisipasi masyarakat adalah UUD 1945 yang menyebutkan bahwa partisipasi adalah hak dasar warga negara, dan partisipasi politik sebagai prinsip dasar demokrasi. Sejak tahun 1999 dikeluarkan berbagaiinstrument hukum berupa UU atau Peraturan Pemerintah (PP) yang membuka lebar ruang bagi partisipasi masyarakat dalam pembuatan kebijakan publik dan monitoring pembangunan.

UUNomor 32 Tahun 2004 tentang Pemerintah Daerah, secara substantif menempatkan partisipasi masyarakat sebagai instrumen yang sangat penting dalam sistem pemerintahan daerah dan berguna untuk mempercepat terwujudnya kesejahteraan sosial, menciptakan rasa memiliki pemerintahan, menjamin keterbukaan, akuntabilitas dan kepentingan umum, mendapatkan aspirasi masyarakat, dan sebagai wahana untuk agregasi kepentingan dan mobilisasi dana.

Selain UUNomor 32 Tahun 2004, berbagai peraturan yang secara sektoral memberikan ruang bagi partisipasi publik diantaranya UUNomor 25 Tahun 2004 tentang Sistem Perencanaan Pembangunan Nasional (SPPN), UU Nomor 7 Tahun 2004 tentang Sumber Daya Air, UUNomor 20 Tahun 2003 tentang Sistem Pendidikan Nasional, UUNomor 23 Tahun 1992 tentang Kesehatan, UUNomor 24 Tahun 1992 tentang Penataan Ruang, UUNomor 41 Tahun 1999 tentang Kehutanan, dan masih banyak lagi peraturan yang secara sektoral mengatur partisipasi masyarakat. Semua peraturan tersebut pada intinya memberikan ruang yang sangat luas pada partisipasi masyarakat dalam menentukan kebijakan publik dan implementasinya

Penyertaan masyarakat sebagai subjek pembangunan adalah suatu upaya mewujudkan tujuan pembangunan nasional.Ini berarti masyarakat diberi peluang untuk berperan aktif mulai dari perencanaan, pelaksanaan hingga evaluasi setiap tahap pembangunan yang diprogramkan.Terlebih apabila kita akan melakukan pendekatan pembangun dengan semangat lokalitas.

Masyarakat lokal dengan pengetahuan serta pengalamannya menjadi modal yang sangat besar dalam melaksanakan pembangunan, karena masyarakat lokal yang mengetahui apa permasalahan yang dihadapi serta potensi yang dimiliki oleh daerahnya. Masyarakat memiliki kedaulatan yang cukup luas untuk menentukan orientasi dan arah kebijakan pembangunan yang dikehendaki.Nilai-nilai kedaulatan selayaknya dibangun sebagai kebutuhan kolektif masyarakat dan bebas dari kepentingan individu dan atau golongan. 
Perlunya keterlibatan masyarakat ini dianggap sangat penting, karena pelaksanaan pembangunan yang mengutamakan masyarakat dalam pelaksanaan program-program pembangunan, berarti memberikan peluang seluas-luasnya kepada masyarakat untuk mengarahkan sumber daya, potensi, merencanakan serta membuat keputusan dan mengevaluasi kegiatan-kegiatan pembangunan yang akan mensejahterakan mereka, sehingga mereka berdaya.

Desa sebagai kesatuan masyarakat hukum terkecil yang memiliki batas-batas wilayah yang berwenang untuk mengatur dan mengurus kepentingan masyarakatnya berdasarkan asal-usul dan adat istiadat setempat yang diakui dan dihormati oleh negara.Pembangunan pedesaan selayaknya mengarah pada peningkatan kesejahteraan masyarakat pedesaan.Pembangunan pedesaan dapat dilihat pula sebagai upaya mempercepat pembangunan pedesaan melalui penyediaan sarana dan prasarana untuk memberdayakan masyarakat, dan upaya mempercepat pembangunan ekonomi daerah yang efektif dan kokoh.

Proses perencanaan pembangunan partisipatif adalah proses perencanaan pembangunan yang mendasari pada kebutuhan masyarakat setempat serta didukung peranserta aktif dari masyarakat dari awal pengidentifikasian masalah hingga tersusunnya dokumen perencanaan pembangunan. Suatu perencanaan pembangunan akan tepat sasaran, tepat waktu, berdayaguna dan berhasil guna apabila perencanaan tesebut benar-benar memenuhi kebutuhan masyarakat, serta adanya peran aktif masyarakat dalam penyusunan rencana pembangunan. Tahapan Musrenbang terdiri dari tiga tahapan yaitu : pertama tahapan persiapan Musrenbang Desa, kedua tahapan pelaksnaan Musrenbang Desa, ketiga tahapan Sosialisasi. Untuk lebih jelasnya lihat gambar dibawah ini: 


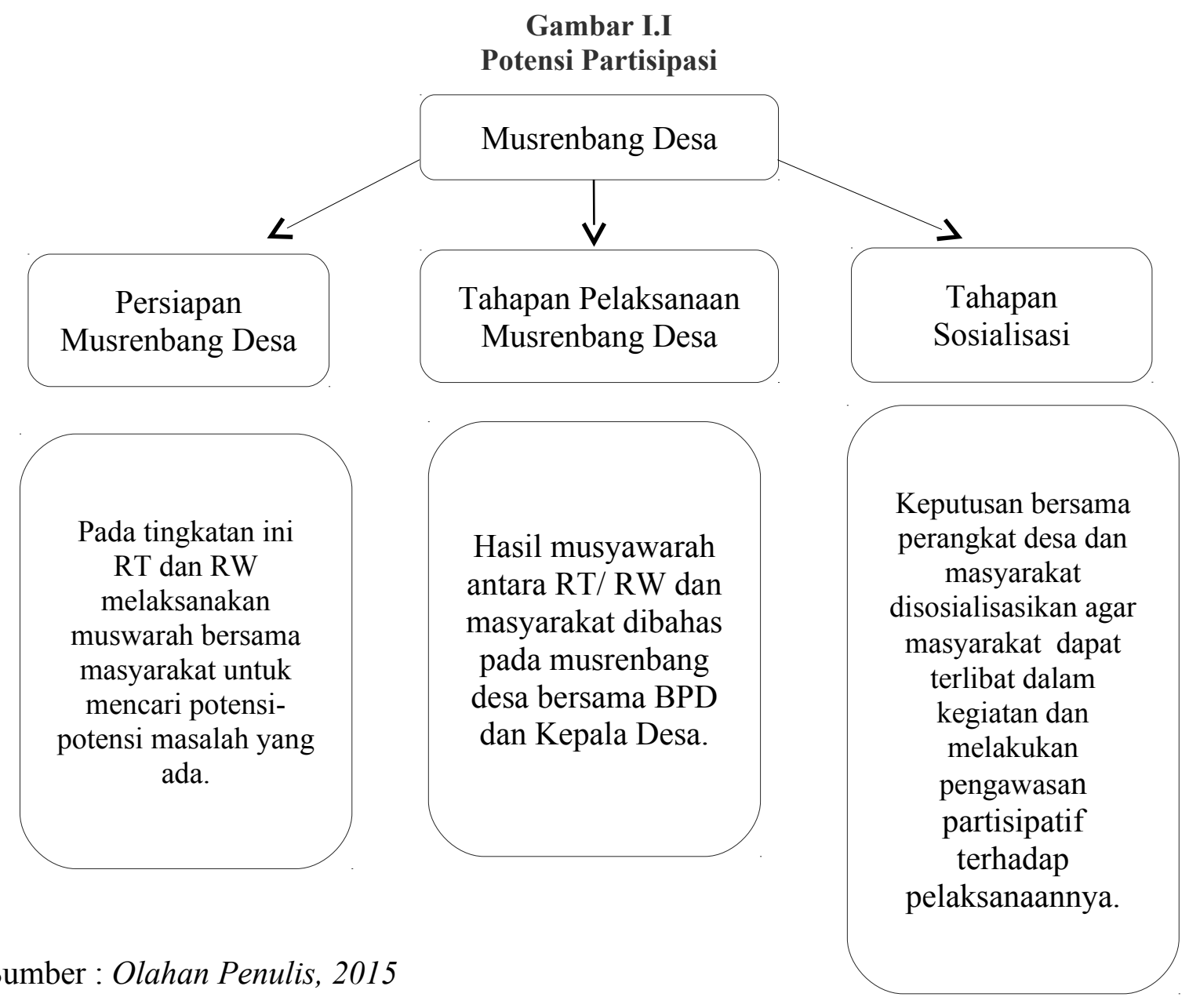

Kepala Desa dan anggota Badan Permusyawaratan Desa (BPD) sebagai pengelola pemerintahan desa, harus memahami arti penting perencanaan pembangunan partisipatif dan melaksanakan pola perencaaan tersebut dalam proses pembangunan di desa. Hal ini kiranya sangat penting, karena sesuai ketentuan pasal 1 angka 12 UU Nomor 32 Tahun 2004 tentang Pemerintahan Daerah menegaskan bahwa desa atau sebutan lain yang selanjutnya disebut desa adalah kesatuan masyarakat hukum yang berwenang mengatur dan mengurus kepentingan masyarakat setempat berdasarkan asal-usul dan adat istiadat setempat yang diakui dalamsistempemerintahannasionalserta berada di daerah kabupaten dan kota.

Berdasarkan ketentuan pasal 1 tersebut di atas, dapat diketahui bahwa UU Nomor 32 Tahun 2004 mengakui adanya otonomi yang dimiliki oleh desa. Di samping otonomi yang dimilikinya, desa (pemerintah desa) juga dapat menerima atau melaksanakan suatu urusan pemerintahan tertentu yang berupa penugasan ataupun pendelegasian dari pemerintah ataupun pemerintah daerah. Dengan demikian desa atau sebutan lain harus dipahami sebagai 
kesatuan masyarakat hukum yang memiliki hak dan kekuasaan dalam mengatur dan mengurus kepentingan masyarakatnya untuk menuju kesejahteraan.

Penjelasan UUNomor 32 Tahun 2004 disebutkan bahwa landasan pemikiran mengenai pengaturan pemerintahan desa adalah keanekaragaman, partisipasi, otonomi asli, demokratisasi dan pemberdayaan masyarakat.Partisipasi di sini dimaksudkan bahwa penyelenggaraan pemerintahan desa harus mampu mewujudkan peran aktif masyarakat agar masyarakat merasa memiliki dan turut bertanggung-jawab terhadap perkembangan kehidupan bersama sebagai sesama warga desa.Sedangkan demokratisasi mengandung pengertian bahwa penyelenggaraan pemerintahan desa harus mengakomodasi aspirasi masyarakat yang diartikulasi dan diagregasi melalui BPD dan lembaga kemasyarakatan sebagai mitra pemerintah desa.

Berdasarkan penjelasan UU Nomor 32 Tahun 2004 juga ditegaskan bahwa substansi pemberdayaan masyarakat adalah penyelenggaraan pemerintahan desa yang diabdikan untuk meningkatkan taraf hidup dan kesejahteraan masyarakat melalui penetapan kebijakan, program, dan kegiatan yang sesuai dengan esensi masalah dan prioritas kebutuhan masyarakat. Pembangunan desa merupakan bagian integral dari pembangunan daerah dan pembangunan nasional.

Sebagai wujud kemampuan melaksanakan kewenangan yang merupakan bagian dari esensi otonomi daerah tersebut, daerah dituntut untuk merumuskan program pembangunan secara komprehensif mulai dari pembangunan tingkat perdesaan hingga kabupaten. Oleh karena itulah, maka keterlibatan atau partisipasi dari masyarakat dalam proses pembangunan mulai dari perencanaan, pelaksanaan, sampai pada evaluasi hasil pembangunan sangat penting utamanya di tingkat desa.

Salah satu prinsip penyelenggaraan otonomi daerah yang perlu mendapat perhatian adalah partisipasi masyarakat dalam penyelenggaraan pemerintahan, khususnya ditingkat desa. UU Nomor 72 Tahun 2005 tentang Desa, pasal 14, ayat 2.g menjelaskan, bahwa Kepala Desa dalam melaksanakan tugas penyelenggaraan pemerintahan, pembangunan dan kemasyarakatan, mempunyai wewenang untuk mengkoordinasikan secara partisipatif.

Hal diatas kemudian memunculkan pertanyaan di kabupaten bintan, khususnya di desa Kuala Sempang Kecamatan Seri Kuala Lobam, apakah partisisipasi masyarakat di dalam pelaksanaan pembangunan telah terlaksana dengan baik, di mana masyarakat tidak lagi menjadi objek pembangunan, akan tetapi telah menjadi subyek pembangunan. Dengan maksud bahwa partisipasi masyarakat dalam pelaksanaan pembangunan bukan hanya sekedar 
dilihat dari antusiasme masyarakat dalam menghadiri Musrenbang, akan tetapi, bagaimana kepentingan mereka telah direspon oleh pemerintah desa, serta bagaimana proses pelibatan masyarakat baik dalam tahap perencanaan sampai tahap pelaksanaan proyek pembangunannya. Karena antusiasme masyarakat kemudian lahir ketika substansi dari proses pembangunan itu telah tercipta.

Kemampuan berpartisipasi terkait dengan kepemelikan sumber daya yang diperlukan perihal partisipasi, baik menyangkut kualitas sumber daya manusia maupun sumberdaya lainnya seperti dana dan tenaga. Aspek yang dapat meningkatkan kualitas sumber daya manusia adalah pendidikan peran pendidikan dianggap cukup tinggi dalam menciptakan peningkatan kualitas sumber daya masyarakat kita.Oleh karena itu, agar kemampuan berpatisipasi dimiliki oleh masyarakat maka diperlukan upaya untuk meningkatkan sumber daya manusia melalui sektor pendidikan.

Akses yang luas terhadap pendidikan akan mempercepat tingginya tingkat pendidikan masyarakat, pada waktunya akan memampukan masyarakat berpartisipasi dalam pembangunan.Seperti yang diketahui bahwa United Nation's Development Program(UNDP) tahun 2004 telah menempatkan Human Development Index (HDI) Indonesia pada urutan 111 dari 175 negara. Bahkan dibanding negara tetangga seperti Malaysia, Thailand, dan Philipina, posisi Indonesia berada dibawah mereka (dalam Aditama, 2008:2).

Pendidikan menjadi salah satu komponen yang digunakan pengukuran HDI.Melihat kondisi yang semacam ini maka tidak aneh jika pembangunan kita jauh tertinggal daripada negara-negara lain yang memiliki kualitas pendidikan lebih baik. Lihat tabel tingkat pendidikan Desa Kuala Sempang berikut:

\section{Tabel 1.1}

Klasifikasi Penduduk Berdasarkan Pada Tingkat Pendidikan Desa Kuala Sempang

\begin{tabular}{|c|l|c|}
\hline No & \multicolumn{1}{|c|}{ Tingkat Pendidikan } & Jumlah (orang) \\
\hline 1 & Tidak tamat SD & 360 \\
\hline 2 & SD & 435 \\
\hline 3 & SLTP & 215 \\
\hline 4 & SLTA / SMK & 160 \\
\hline 5 & Diploma & 11 \\
\hline 6 & Sarjana & 11 \\
\hline
\end{tabular}

Sumber : Profil Desa Kuala Sempang Kecamatan Seri Kuala Lobam Kabupaten Bintan 2011-2015.

Maka jika dilihat dari tabel diatas jumlah penduduk kuala sempang berdasarkan pendidikan yang tidak tamat SMA atau bersekolah sampai dengan tingkat SLTP berjumlah 
1010 orang, dan sisanya adalah tamatan SMA, Diploma dan Sarjana.Melalui penelitian awal, ditemukan bahwa dalam pelaksanaan perencanaan pembangunan di Desa Kuala Sempang sudah berjalan cukup baik proses perencanaannya dimana terlihat pelaksanaan perencanaan pembangunan dari mulai tingkat Rukun Tetangga (RT) dan Rukun Warga (RW) bekerja sama dalam menjaring potensi masalah-masalah yang ada, aspirasi masyarakat diterima untuk diusulkan kepada BPD dan Kepala Desa pada saat perumusan rencana pembangunan desa di Desa Kuala Sempang.

Hal ini dapat dilihat tabel dibawah ini mulai dari perencanaan pembangunan desa dari RT dan RW hingga keputusan rapat yang menghasilkan usulan-usulan yang diterima untuk dilaksanakan dalam pembangunan desa Kuala Sempang:

Tabel 1.2

Rencana Pembangunan Jangka Menengah Desa Tahun 2011-2015 yang diusulkan dari tingkat RT dan RW

\begin{tabular}{|l|l|c|}
\hline \multicolumn{1}{|c|}{ Rt $/$ Rw } & \multicolumn{1}{|c|}{ Lokasi } & Jumlah Usulan Yang di Ajukan \\
\hline Rt 01/01 & Kp. Sempang & 15 \\
\hline Rt 01/02 & Tg. Arang & 19 \\
\hline Rt 01/03 & Kp. Limau & 8 \\
\hline Rt 01/04 & Kp. Pelita Baru & 13 \\
\hline Rt 01/05 & Kp. Beringin & 3 \\
\hline
\end{tabular}

Sumber : Rencana Pembangunan Jangka Menengah Desa Kuala Sempang Tahun 20112015.

Berdasarkan tabel diatas terlihat bahwa RT dan RW mampu menemukan potensi masalah yang ada di lingkungannya yang akan diajukan pada saat musyawarah Kegiatan Rencana Kerja Pembanungan Desa (RKPDes).

Tabel 1.3

Data Rencana Pembangunan Infrastruktur di Desa Kuala Sempang Tahun 2011- 2015

\begin{tabular}{|l|l|c|l|}
\hline No & \multicolumn{1}{|c|}{ Infrastruktur Pedesaan } & Volume & \multicolumn{1}{c|}{ Lokasi } \\
\hline 1 & Pipanisasi & 3 Kilometer (km) & $\begin{array}{l}\text { Kampung (Kp). } \\
\text { Simpang - } \\
\text { Tanjung (Tg). } \\
\text { Arang }\end{array}$ \\
\hline 2 & $\begin{array}{l}\text { Drainase, batu miring, dan jembatan } \\
\text { kecil }\end{array}$ & $200 \mathrm{~m}$ & Kp. Simpang \\
\hline 3 & Perkerasan Jalan & $3 \mathrm{~km} \mathrm{x} \mathrm{4} \mathrm{meter} \mathrm{(m)}$ & Kp. Limau \\
\hline 4 & Penimbunan dan Batu Miring & $300 \mathrm{~m}$ & Sei. Lepan \\
\hline 5 & $\begin{array}{l}\text { Gedung TPA dan PAUD } \\
\text { Kp. Pelita Baru } \\
\text { dan Tg. Arang }\end{array}$ \\
\hline 6 & $\begin{array}{l}\text { Pendirian SMK 3 Ruang Kelas } \\
\text { Belajar }\end{array}$ & $12 \mathrm{~m}$ & Kp. Limau \\
\hline
\end{tabular}




\begin{tabular}{|l|l|c|l|}
\hline 7 & Rehab Jembatan & $30 \times 2,5 \mathrm{~m}$ & Kp. Beringin \\
\hline 8 & Pagar SDN 002 Seri Kuala Lobam & $600 \times 1,5 \mathrm{~m}$ & Kp. Simpang \\
\hline 9 & Sarana Olah Raga & 1 Unit & Kp. Pelita Baru \\
\hline 10 & Sumur Bor dan MCK & 6 Unit & Kp. Pelita Baru \\
\hline No & \multicolumn{1}{|c|}{1} & 2 & 3 \\
\hline 11 & Keramba Budidaya Laut & 10 Unit & Kp. Simpang \\
\hline 12 & Alat Tangkap Pompong & 10 Unit & $\begin{array}{l}\text { Kp. Simpang, } \\
\text { Arang, Sei Lepan } \\
\text { dan Pelita Baru }\end{array}$ \\
\hline 13 & Perkerasan Jalan & $3 \mathrm{~km} \mathrm{x} 4 \mathrm{~m}$ & Tg. Arang \\
\hline 14 & Pagar SDN 004 Seri Kuala Lobam & $600 \times 1,5 \mathrm{~m}$ & Kp. Pelita Baru \\
\hline
\end{tabular}

Sumber: Rencana Pembangunan Jangka Menengah Desa (RPJMDes) Tahun 2011-

2015 Desa Kuala Sempang Kecamatan Seri Kuala Lobam Kabupaten Bintan.

Tabel 1.4

Nilai Kegiatan Yang Menggunakan Dana Alokasi Khusus Untuk Dikelola Oleh Pemerintah Desa dan Masyarakat Tahun 2011-2015

\begin{tabular}{|l|c|}
\hline \multicolumn{1}{|c|}{ Infrastruktur Pedesaan } & Jumlah Dana \\
\hline Perkerasan Jalan & Rp. 120.000 .000 \\
\hline Pipanisasi & Rp. 187.500 .000 \\
\hline Gedung TPA & Rp. 180.000 .000 \\
\hline Gedung PAUD & Rp. 180.000 .000 \\
\hline Pagar SD 004 & Rp. 40.000 .000 \\
\hline Pagar SD 002 & Rp. 40.000 .000 \\
\hline Alat Tangkap Nelayan & Rp. 80.000 .000 \\
\hline Bantuan Keramba Ikan & Rp. 180.000 .000 \\
\hline
\end{tabular}

Sumber: Rencana Pembangunan Jangka Menengah Desa (RPJMDes) Tahun 2011-

2015 Desa Kuala Sempang Kecamatan Seri Kuala Lobam Kabupaten Bintan.

Data nilai kegiatan pada tabel diatas merupakan data pembangunan infrastruktur yang dalam palaksanaannya akan dikerjakan oleh pemerintah desa dan masyarakat desa selebihnya yang tidak terdaftar dalam tabel ini, pelaksanaan pembangunannya dilaksanakan melalui pihak ketiga namun tetap mengikutsertakan masyarakat desa.Berdasarkan tabel diatas dalam partisipasi masyarakat Desa Kuala Sempang dari penelitian awal bahwa masyarakat berpatisipasi dalam pembangunan desa baru terilihat dalam partisipasi pemikiran yang disampaikan kepada BPD dan Kepala Desa yang diusulkan dalam Rencana Pembangunan Desa.

Padahal masyarakat diberikan peluang untuk ikut serta dalam pembangunan tersebut mulai dari perencanaan, pelaksanaan hingga evaluasi pada suatu program yang dijalankan pemerintah desa. Proses pembangunan partisipatif adalah proses perencanaan yang mendasari kebutuhan masyarakat setempat, pembangunan akan berhasil apabila perencanaan 
pembangunan tersebut benar-benar memenuhi kebutuhan masyarakat dalam penyususnan pembangunan tersebut.

Berdasarkan beberapa kondisi di atas penulis maka kajian ini berupaya mengkaji Partisipasi Masyarakat Dalam Pembangunan di Desa Kuala Sempang Kecamatan Seri Kuala Lobam Kabupaten Bintan Tahun 2014.

\section{KAJIAN TEORI}

\section{KONSEP PEMBANGUNAN}

Hakekat pembangunan adalah proses perubahan yang terus menerus yang merupakan kemajuan dan perbaikan menuju ke arah yang ingin dicapai, selanjutnya untuk memberikan ini S.P. Siagian(dalam Andi Ripai, 2013:49) memberikan defenisi sebagai berikut :

"Pembangunan adalah suatu usaha atau rangkaian usaha pertumbuhan dan perubahan berencana yang dilakukan secara sadar oleh suatu bangsa, Negara dan pemerintah menuju modernitas dalam rangka pembinaan bangsa." Siagian (dalam Andi Ripai, 2013:49)

"Pembangunan adalah proses perubahan berbagai dimensi kehidupan manusia yang berlangsung terus-menerus. Perubahan ini bisa terjadi dengan sendirinya bisa juga dengan pengaruh atau arahan dari pemerintah (dalam I. Nyoman Sumaryadi, 2005:25).Todaro(dalam A. Umar Mustari, 2000:28), menyatakan bahwa pembangunan bukan hanya fenomena semata, namun pada akhirnya pembangunan tersebut harus melampaui sisi materi dan keuangan dari kehidupan manusia."

Menurut Hanif Nurcholis (2011:108) penyusunan perencanaan pembangunan desa harus di dasarkan pada data dan informasi yang akurat dan dapat dipertanggungjawabkan. Data dan informasi yang di perlukan dalam peyusunan perencanaan pembangunan mencakup:

1. Penyelenggaraan pemerintah desa.

2. Organisasi dan tata laksana pemerintahan desa.

3. Keuangan desa.

4. Profil desa.

5. Informasi lain terkait dengan penyelenggaraan pemerintah desa dan pemberdayaan masyarakat.

Pembangunan partisipatif adalah suatu sistem pengelolaan pembangunan di desa bersama-sama secara musyawarah, mufakat, dan gotong royong yang merupakan cara hidup masyarakat yang telah lama berakar budaya di wilayah Indonesia.(Peraturan Menteri Dalam Negeri No 66 Tahun 2007). 


\section{KONSEP PARTISIPASI}

Partisipasi sebagai salah satu elemen pembangunan merupakan proses adaptasi masyarakat terhadap perubahan yang sedang berjalan.Partisipasi adalah penentuan sikap dan keterlibatan hasrat setiap individu dalam situasi dan kondisi organisasinya, sehingga pada akhirnya mendorong individu tersebut untuk berperan serta dalam pencapaian tujuan organisasi, serta ambil bagian dalam setiap pertanggungjawaban bersama (dalam Syafiie, Inu Kencana. 2009:141).

Berkaitan dengan proses pembangunan Adisasmita (dalam Solekhan, 2012:20) mengatakan bahwa partisipasi masyarakat merupakan keterlibatan dan pelibatan anggota masyarakat dalam pembangunan meliputi kegiatan dalam perencanaan dan pelaksanaan program atau proyek pembangunan yang dikerjakan dimasyarakat lokal. Sedangkan dalam konteks perencanaan, UU Nomor 25 Tahun 2004 (penjelasan pasal 2 ayat 4 huruf d) menjelaskan bahwa partisipasi masyarakat merupakan keikutsertaan masyarakat untuk mengakomodasikan kepentingan mereka dalam penyusunan rencana pembangunan.

Gaventa dan Valderama (dalam Solekhan, 2012:31) menengaskan bahwa partispasi warga telah mengalihkan konsep partipasi dari sekedar kepedulian terhdap penerima derma atau kaum tersisih menuju ke suatu kepedulian dengan pelbagai bentuk keikutsertaan warga dalam pembuatan kebijkan dan pengambilan keputusan diberbagai gelanggang kunci yang mempengaruhi kehidupan mereka. Lebih dari pada itu, partisipasi warga juga terefleksikan dalam berbagai bentuk, Rusidi (dalam Solekhan, 2012:32) mengatakan ada empat dimensi dalam berpartisipasi, yang terdiri dari :

a. Sumbangan pemikiran (ide atau gagasan).

b. Sumbangan materi (dana dan barang).

c. Sumbangan tenaga (bekerja).

d. Memanfaatkan pembangunan.

Sumbangan pemikiran adalah bagaimana masyarakat memberikan ide pemikiran untuk pembangunan dan kemajuan di desa, sumbangan materi yang diberikan dari masyarakat untuk pemerintah desa pada saat tahapan pelaksanaan pembangunan,sumbangan tenaga adalah sumbangan atau keikut sertaan masyarakat tempatan dalam proses pembangunan desa dan memanfaat pembangunan yang sudah terlaksana bagaimana masyarakat memanfaatkannya dan menjaganya. 
Pandangan lain tentang bentuk-bentuk partisipasi warga tersebut disampaikan oleh Cohen dan Uphoff (dalam Solekhan, 2012:32) yang mengatakan bahwa bentuk-bentuk partisipasi warga itu dibagi menjadi empat bentuk partisipasi, yang terdiri dari:

1. Partisipasi dalam pembuatan keputusan (participation in decision making).

2. Partisipasi dalam pelaksanaan (participation in implementation).

3. Partisipasi dalam menerima manfaat (participation in benefits).

4. Partispasi dalam evaluasi (participation in evaluation).

Sebagaimana dijelaskan oleh Eko bahwa partisipasi merupakan jembatan penghubung antara Negara dan masyarakat agar pengelolaan barang-barang publik membuahkan kesejahteraan. (dalamSolekhan, 2012:9). Secara subtantif, partisipasi menyangkut tiga hal, yaitu:

a. Suara (Voice), yang artinya bahwa setiap masyarakat itu mempunyai hak dan ruang untuk menyampaikan suara dalam proses pemerintahan, sebaliknya pemerintah mengakomodasi setiap suara yang berkembang dalam masyarakat yang kemudian dijadikan sebagai basis pembuatan keputusan.

b. Akses, yaitu bahwa setiap warga masyarakat itu mempunyai kesempatan untuk mengakses atau memengaruhi pembuatan kebijakan, termasuk asks dalam layanan public dan akses pada arus informasi.

c. Kontrol, yaitu bahwa setiap warga masyarakat mempunyai kesempatan dan hak untk melakukan pengawasan terhadap jalannya pemerintahan.

\section{KONSEP PARTISIPASI MASYARAKAT}

Partisipasi masyarakat adalah ikut sertanya seluruh anggota masyarakat dalam memecahkan permasalahan-permasalahan masyarakat tersebut.Geddesian (dalam Irma Purnamasari, 2008:43) mengemukakan bahwa pada dasarnya masyarakat dapat dilibatkan secara aktif sejak tahap awal penyusunan rencana. Keterlibatan masyarakatdapat berupa:

a. Pendidikan melalui pelatihan.

b. Partisipasi aktif dalam pengumpulan informasi.

c. Partisipasi dalam memberikan alternatif rencana dan usulan kepada pemerintah.

Menurut Juliantara (dalam Irma Purnamasari, 2008:45) substansi dari partisipasi adalah bekerjanya suatu sistem pemerintahan dimana tidak ada kebijakan yang diambil tanpa adanya persetujuan dari rakyat, sedangkan arah dasar yang akan dikembangkan adalah proses pemberdayaan, lebih lanjut dikatakan bahwa tujuan pengembangan partisipasi adalah: 
1. Pertama, bahwa partisipasi akan memungkinkan rakyat secara mandiri (otonom) mengorganisasi diri, dan dengan demikian akan memudahkan masyarakat menghadapi situasi yang sulit, serta mampu menolak berbagai kecenderungan yang merugikan.

2. Kedua, suatu partisipasi tidak hanya menjadi cermin konkrit peluang ekspresi aspirasi dan jalan memperjuangkannya, tetapi yang lebih penting lagi bahwa partisipasi menjadi semacam garansi bagi tidak diabaikannya kepentingan masyarakat.

3. Ketiga, bahwa persoalan-persoalan dalam dinamika pembangunan akan dapat diatasi dengan adanya partisipasi masyarakat. (Juliantara, 2002: 89-90).

Partisipasi masyarakat menurut Isbandi (2007: 27) adalah keikutsertaan masyarakat dalam proses pengidentifikasian masalah dan potensi yang ada di masyarakat, pemilihan dan pengambilan keputusan tentang alternatif solusi untuk menangani masalah, pelaksanaan upaya mengatasi masalah, dan keterlibatan masyarakat dalam proses mengevaluasi perubahan yang terjadi.

Partisipasi masyarakat menurut Isbandi (dalam Saca Firmansyah, 2009:1) adalah keikutsertaan masyarakat dalam proses pengidentifikasian masalah dan potensi yang ada di masyarakat, pemilihan dan pengambilan keputusan tentang alternatif solusi untuk menangani masalah, pelaksanaan upaya mengatasi masalah, dan keterlibatan masyarakat dalam proses mengevaluasi perubahan yang terjadi.Sementara itu menurut Sanoff (dalam Andi Ripai, 2013:26), tujuan utama partisipasi adalah:

a. Untuk melibatkan masyarakat dalam proses pembuatan desain keputusan.

b. Untuk melengkapi masyarakat dengan suatu suara dalam membuat desain keputusan untuk memperbaiki rencana.

c. Untuk mempromosikan masyarakat dengan membawanya bersama sebagai bagian dari tujuan umum. Dengan partisipasi, masyarakat secara aktif bergabung dalam proses pembangunan, lingkungan fisik yang lebih baik, semangat publik yang lebih besar, dan lebih puas hati.

Menurut Notoatmodjo (dalam SA. Harahap, 2011:3)didalam partisipasi setiap anggota masyarakat dituntut suatu kontribusi atau sumbangan. Kontribusi tersebut bukan hanya terbatas pada dana dan finansial saja tetapi dapat berbentuk daya (tenaga) dan ide (pemikiran).Dalam hal ini dapat diwujudkan di dalam empat (4) M, yakni manpower (tenaga), money (uang), material (benda-benda lain seperti kayu, bambu, beras, batu, dan sebagainya), dan mind (ide atau gagasan). 


\section{KONSEP OPERASIONAL TEORI RUSIDI}

Kajian ini menggunakan grand Teori Rusidi (dalam Solekhan, 2012:32) dengan empat dimensi dalam partisipasi, yang terdiri dari:

a) Sumbangan pemikiran (ide atau gagasan), yaitu Partisipasi masyarakat dalam bentuk pemikiran dalam persiapan musrenbang. B) Sumbangan materi (dana dan barang), yaitu Partisipasi masyarakat dalam bentuk sumbangan dana dan Partisipasi masyarakat dalam bentuk barang. C) Sumbangan tenaga (bekerja), yaitu Partisipasi masyarakat dalam bentuk tenaga kerja.d) Memanfaatkan pembangunan, yaitu Partisipasi masyarakat dalam pemanfaatan penmbangunan yang telah terlaksana dan perawatan rutin.

\section{METODE PENELITIAN}

Kajian penelitian ini merupakan penelitian kualitatif, Menurut Moleong (2010:6) adalah penelitian yang bermaksud untuk memahami fenomena tentang apa yang dialami oleh subjek penelitian misalnya perilaku, persepsi, motivasi, tindakan dan lain-lain, secara holistic dan dengan cara deskripsi dalam bentuk kata-kata dan bahasa, pada suatu konteks khus yang alamiah dan dengan memanfaatkan berbagai meteode alamiah. Data Primer diperoleh dengan melakukan penelitian langsung terhadap objek penelitian dengan menggunakan teknik pengumpulan data observasi, interview atau wawancara, yaitu melakukan tanya jawab secara langsung dengan informan yang telah dipilih dalam hal pengumpulan informasi yang relavan. Data sekunder diperoleh melalui study pustaka untuk mengumpulkan data - data melalui buku - buku, peraturan - peraturan, dan dokumen yang ada relevansinya dengan penelitian.

Subjek penelitian adalah orang-orang yang mengetahui dan memiliki berbagai informasi pokok, menjadi informan yang akan memberikan berbagai informasi yang diperlukan selama proses penelitian.

\begin{tabular}{|c|l|c|}
\multicolumn{2}{|c|}{ Tabel Informan } \\
\hline NO & \multicolumn{1}{|c|}{ RESPONDEN } & JUMLAH \\
\hline 1. & Kepala Desa Kuala Sempang & 1 Orang \\
\hline 2. & Ketua BPD Desa Kuala Sempang & 1 Orang \\
\hline 3. & Masyarakat Desa Kuala Sempang & 5 Orang \\
\hline \multicolumn{2}{|c|}{ JUMLAH } & 7 Orang \\
\hline
\end{tabular}

Sumber : Data Olahan Penulis, 2015

Teknik analisis data yang digunakan dalam penelitian ini adalah teknik triangulasi, teknik triangulasi adalah teknik pemeriksaan keabsahan data memanfaatkan sesuatu yang lain. Di luar data itu untuk keperluan pengecekan atau sebagai pembanding terhadap data itu.Teknik triangulasi yang paling banyak digunakan adalah pemeriksaan melalui sumber 
lainnya.Denzim (dalam Moleong, 2010:330) membedakan empat macam triangukasi sebagai teknik pemeriksaan yang memanfaatkan penggunaan suber, metode, penyidik, dan teori.

\section{HASIL DAN PEMBAHASAN}

\section{PARTISIPASI PEMIKIRAN}

Masyarakat ikut terlibat dalam pengerjaan proyek pembangunan pipanisasi di desa kuala sempang karena kesadaran akan pentingnya mereka ikut serta sebagai masyarakat tempatan untuk berpartisipasi dalam pembangunan pipanisasi, karena jika mereka sebagai masyarakat tidak bergerak dengan ikut serta dalam pembangunan desa maka mereka sendiri yang akan merasakan dampak kesulitan dalam menjalani kehidupannya. Dengan adanya semangat gotong royong bersama pemerintah desa mereka sadar betul tentang pembangunan pipanisasi akan memiliki dampak yang baik bagi daerah yang membutuhkan air bersih dan membutuhkan air sebagai sebagai sumber kehidupan, partisipasi masayrakat dimaksud merupakan wujud nyata kerjasama antara pemerintah desa dengan warga desanya. Dijelaskan oleh Kepala Desa Kuala Sempang bahwa :

"Pemikiran memperjuangkan pengadaan pipanisasi di Desa Kuala Sempang bukanlah hal baru.Masyarakat Desa Kuala Sempang khususnya di tiga dusun yang membutuhkan sumber air bersih yakni dusun simpang jembatan, simpang centre dan tanjung arang. Keputusan tentang pembuatan pipanisasi air bersih sepanjang tiga kilometer bukan merupakan keputusan Kepala Desa dan aparatnya saja melainkan merupakan hasil keputusan Musyawarah Desa yang pada dasarnya merupakan masukan dari warga desa utamanya tokoh masyarakat yang bersemangat memperjuangkan pembangunan ini" (Kades Desa Kuala Sempang bapak Selamat, wawancara: 14 juni 2015)

Selanjutnya, kepala Desa menuturkan :

"Didalam pelaksanaan pembangunan pipanisasi masyarakat dilibatkan untuk bagaimana proses pelaksanaanya, dan masyarakat yang setempatlah yang melaksanakannya, walaupun pada pelaksanaannya tidak semua warga bisa membantu karena kesibukan banyak masyarakat yang kerja diluar desa namun dengan adanya masyarakat atau tim yang dibentuk untuk memperkerjakan pembangunan tersebut alhamulillah tetap berjalan dengan baik"(Kades Desa Kuala Sempang bapak Selamat, wawancara:14 juni 2015)

Sebagian masyarakat juga memberikan masukan pikiran-pikiran teknis dalam pelaksanaan pembangunan fisik pipanisasi tersebut. Antara lain adalah partisipasi ide dengan mengusukan agar pemanfaatan pipanisasi tidak hanya satu dusun saja namun di dusun-dusun yang masih memiliki kesulitan untuk menjangkau air bersih juga harus ada sistem pipanisi ini agar masyarakat lain juga merasakan manfaat yang besar dengan adanya pipanisasi air masukan hal itu di terima oleh Kepala Desa dan selanjutnya dilanjutlah pembangunan pipanisasi tersebut. Hal tersebut disampaikan oleh Kepala Desa Kuala Sempang, bahwa: 
"Pada saat pemasangan jalur pipanisasi dikerjakan, banyak anggota masyarakat yang terlibat tanpa melihat berapa upah yang mereka dapatkan, karena mereka menganggap bahwa pentingnya pembangunan pipanisasi ini untuk kehidupan mereka sehari-hari, mereka juga menunjuk tim sebagai pengelola teknis pipanisasi tersebut."(Kades Kuala Sempang bapak Selamat, wawancara 14 juni 2015)

Tentunya keberhasilan suatu proses pembangunan yang dilaksanakan oleh pemerintah desa tidak lepas dari peran masyarakat itu sendiri, tahapan ide-ide masyarakat dalam pembangunan desa tentu dibutuhkan untuk menjadi bahan pertimbangan pemerintah desa demi perkembangan kemajuan desa.

\section{PARTISIPASI MATERI DANA ATAU BARANG}

Tentu untuk pengadaan pipanisasi sepanjang tiga kilometer dan dipasang kerumahrumah dana yang diperlukan harus lebih dari yang dianggarkan, dari dana awalnya hanya bisa digunakan untuk pipa induk saja belum bisa untuk mencapai dari rumah-kerumah.Dengan mencoba untuk terus berjuang agar pembangunan ini selesai pemerintah desa mengajak untuk masyarakat memberikan subangan suka rela agar bisa menutupi kekurangan dana pembangunan tersebut. Sebagaimana yang disampaikan oleh bapak Selamat:

"Dengan keterbatasan dana yang dimiliki pemerintah desa maka dengan inisiatif masyarakat tergerak hatinya untuk memberikan sumbangan secara sukarela agar pembangunan yang sedang berlangsung terus berjalan dan dapat dirasakan manfaatnya oleh masyarakat di Desa Kuala Sempang. Pada pertemuan Desa."Kepala Desa Kuala Sempang Bapak Selamat, wawancara: 14 juni 2015).

Himbauan tersebut ternyata disambut baik oleh warga dan tokoh masyarakat, sambutan baik itu dimaksudkan adalah masyarakat memberikan sumbangan dana sukarela pada saat tahapan pelaksanaan untuk digunakan oleh tim pelaksana pembangunan desa agar menggunakan untuk membeli kelengkapan sesuai kebutuhanya. Sebagaimana yang dikemukakan oleh Tokoh Masyarakat Desa Kuala Sempang bahwa:

"Mengenai partisipasi dalam bentuk uang memang diberikan masyarakat dalam pembangunan pipanisasi ini namun tidak semua dimintai sumbangan yang dianggap lebih tingkat ekomominya maka dimintai dana sumbangan sukarela."(Tokoh Masyarakat Desa Kuala Sempang Bapak Muhammad Latif, wawancara 15 juni 2015)

\section{PARTISIPASI MASYARAKAT DALAM BENTUK BARANG}

Partisipasi dalam bentuk barang sebagaimana yang dijelaskan oleh Kepala Desa Kuala Sempang bahwa:

"Di dalam pelaksanaan pembangunan pipanisasi di Desa Kuala Sempang memang tidak ada masyarakat yang memberikan sumbangan dalam bentuk barang yang diberikan oleh masyarakat adalah partisipasi dalam bentuk dana yang diberikan untuk pembangunan pipanisasi."(Kepala Desa Kuala Sempang bapak Selamat, wawancara: 14 juni 2015) 
Masyarakat memang dalam hal partisipasi dalam bentuk barang tidak memberikan barang dikarenakan pada saat penyapaian infomasi dalam pembangunan adalah dana yang telah diberikan kepada pemerintah deasa memang akan digunakan untuk pembelanjaan perlengkapan kekurangan barang dalam pembangunan pipanisasi tersebut. Selanjutnya yang disampaikan oleh ketua BPD Desa Kuala Sempang Mengenai partisipasi barang yakni:

"Selama ini memang dalam pelaksanaannya kami selaku BPD juga tidak pernah memberikan sumbangan dalam bentuk barang yang kami berikan adalah dalam bentuk dana sama dengan yang diberikan oleh masyarakat."(Ketua BPD Desa Kuala Sempang, wawancara 14 juni 2015)

Dengan hasil wawancara diatas dapat disimpulkan memang pada kenyataan dilapangan tidak ditemukan partisipasi masyarakat dalam bentuk barang melainkan partisipasi masayarakat yang diberikan oleh masyarakat di Desa Kuala Sempang adalah partisipasi dalam bentuk dana yang diberikan sukarela lantas digunakan untuk kebutuhan pembangunan pipanisasi yang sedang berlangsung.

\section{PARTISIPASI TENAGA}

Partisipasi tenaga yang dimaksudkan adalah bagaimana masyarakat di Desa Kuala Sempang terlibat secara langsung dalam proses pembangunan, Sebagaimana yang disampaikan oleh Kepala Desa Kuala Sempang adalah:

"Di Desa Kuala Sempang gotong royong dilaksanakan dalam sebulan sekali melihat kondisi alam maksudnya adalah melihat cuaca saat melaksanakan pembersihan jalan, masjid, dan kantor desa. Serta kegiatan yang membutuhkan masyarakat secara langsung. "(Kepala Desa Kuala Sempang Bapak Selamat, wawancara: 14 juni 2015).

Sebagaimana yang disampaikan oleh Bapak Selamat selaku Kepala Desa Kuala Sempang banyak anggota masyarakat yang menyertakan diri pada saat perencanaan dan pelaksanaan pembangunan pipanisasi di Desa Kuala Sempang ini karena memang masyarakat sadar betul akan pentingnya sumber air yang akan mereka dapatkan dengan adanya fasilitas yang dimiliki oleh pemerindah desa meskipun didalam penyelanggaraanya terdapat anggaran untuk pembangunan tersebut namun para anggota masyarakat tidak memikirkan nilai upah yang akan diberikan namun mereka menilai manfaat yang akan mereka rasakan ketika pembangunan pipanisasi ini telah berjalan dengan baik. Sebagaimana yang disampaikan oleh ketua BPD Desa Kuala Sempang:

"Selain penyertaan dari masyarakat Desa Kuala Sempang, khususnya BPD juga membantu tenaga ikut dalam pelaksanaan pipanisasi ini walaupun tidak semuanya ikut serta,"(Ketua BPD Desa Kuala Sempang, wawancara 14 juni 2015). 
Partisipasi di Desa Kuala Sempang memang harus diakui dapat dikatakan bahwa masyarakat sudah ikut berpartisipasi didalam pembangunan desa kuala sempang sebagaimana cita-cita pemerintah desa adalah mensejahterakan masyarakat di desa ini salah satunya caranya menempatkan masyarakat didalam perencanaan dan pengerjaan pembangunan desa karena semua manfaatnya adalah untuk masyarakat dari masyarakat yang memberikan ide dan pelaksanaan oleh masyarakat dan dampak dan manfaatnya juga akan diraksanan seluruh masyarakat. Walaupun harus menerima kenyataan pada saat pelaksanaan ada anggota masyarakat yang harus kerja di luar desa untuk mencari nafkah untuk mencari nafkah keluarga mereka sehari-hari.

Penyertaan masyarakat didalam pembangunan desa tidak ada sama sekali unsur paksaan namun kesadaran masyarakat untuk ikut serta dalam pembangunan desa itu memang muncul dari diri masyarakat yang mereka berikan adalah parisipasi tenaga pada saat pelaksanaan pembangunan pipanisasi adalah suatu upaya untuk mewujudkan dan percepatan penyelesaian pembangunan pipanisi yang ada di Desa Kuala Sempang .

\section{PARTISIPASI PEMANFAATAN}

Suatu pembangunan itu bermanfaat ketika memang pembanguna itu dilaksanakan untuk kebutuhan masyarakat dan manfaatnya bisa dirasakan oleh masyarakat desa, sebagaimana yang disampaikan oleh Ketua BPD Desa Kuala Sempang :

"Memang masyarakat sangat terasa terbantu dengan adanya fasilitas air bersih yang disalurkan melalui pipanisasi ini yang sebelumnya sumber air jauh dari jangkauan rumah namun sekarang masyarakat dengan mudah mendapatkan air dirumah mereka karena sudah ada saluran pipa-pipa air yang tersambung dirumah masyarakat,"(Ketua BPD Desa Kuala Sempang, wawancara 14 juni 2015)

Informasi yang diberikan oleh Ketua BPD ini menunjukkan bahwa seluruh masyarakat sangat terbantu dengan adanya fasilitas yang ada dan bisa dimanfaatkan bersama seluruh masyarakat di Desa Kuala Sempang yang tadinya kesulitan dengan jauhnya air namun saat ini sudah mudah untuk menemukan air bersih tidak perlu membeli atau pergi ke kolam air karna pipa air yang dikerjakan oleh pemerintah desa dan masyarakat telah masuk kerumah-rumah masyarakat dan sepenuhnya bisa digunakan. Selanjutnya dipaparkan oleh Tokoh Masyarakat, bahwa:

"Perjuangan masyarakat di Desa Kuala Sempang mengenai pembangunan pipanisasi ini sudah lama ingin dilaksanakan namun memang pada saat tahun 2009 tidak dimanfaatkan awalnya hanya ada mesin dan bak air nya saja belum ada pipa saluran untuk menuju kerumah-rumah warga yang membutuhkan air, selah semangat gotongroyong itu muncul kembali akhirnya pada awal tahun 2013 sampai dengan tahun 2014 penyelesaian pembangunan pipanisasi ini rampung dengan semangat perjuangan seluruh aparat desa dan 
masyarakat desa akhirnya sudah bisa dirasakan oleh warga Desa Kuala Sempang yang berada didua dusun yaitu dusun Tanjung Arang dan Simpang centre."(Tokoh Masyarakat Shalahuddin Syah, wawancara 15 juni 2015)

Selanjutnya yang dipaparkan oleh Tokoh Masyarakat :

"Sangat terasa manfaat dari adanya pipanisi ini karna memudahkan masyarakat mendapatkan air dirumah mereka,dari yang awalnya 18 rumah yang bisa menikmati program ini lantas perlahan menjadi 33 rumah akhir tahun 2015 sudah 83 rumah yang menggunakan sistem pipanisasi air ini yang mana sisa beberapa rumah memang belum terjangkau karna memang jaraknya terlalu jauh dari hasil swadaya pun uangnya belum mencukupi untuk membeli pipa induk air jadi harus menunggu bantuan dari pemerintah daerah dahulu.Memang seluruh masyarakat di Desa Kuala Sempang sangat berterima kasih kepada pemerintah desa karena sudah mau sama-sama memperjuangkan masyarakat yang membutuhkan air bersih hingga pembangunan ini benar-benar terlaksana."(Tokoh Masyarakat Muhammad Latif, wawancara 14 juni 2015)

Pembangunan pipanisasi ini memang bermanfaat bagi seluruh warga di Desa Kuala Sempang yang membutuhkan tak heran jika yang awalnya masih meragukan dengan program ini namun mereka mengikuti rekan-rekan sesame masyarakat untuk memasang saluran pipa untuk mendapatkan sumber air yang bersih dan tidak perlu membeli air dan jauh-jauh pergi mencari air bersih, memang seluruh masyarakat di Desa Kuala Sempang sangat berterima kasih kepada pemerintah desa.

\section{PENUTUP}

Berdasarkan hasil penelitian yang didapat bahwa partisipasi masyarakat dalam pembangunan di Desa Kuala Sempang Kecamatan Seri Kuala Lobam Kabupaten Bintan Tahun 2014 berjalan dengan baik. Hal tersebut disebabkan beberapa indikator, yaitu pertama, Partisipasi Tenaga, Kedua, bentuk partisipasi dalam pemanfaatannya.Ketiga yaitu partisipasi pemikiran masyarakat, Keempat adalah partisipasi materi dalam bentuk dana. Temuan di lapangan membuktikan bahwa sumbangan terbesar masyarakat dalam pertisipasi masyarakat dalam pembangunan pinisasi adalah partisipasi tenaga. Kemudian diikuti oleh Sumbangan materi yang juga penting di saat dana desa tidak cukup dan di bantu oleh masyarakat untuk memperlancarkan proyek pipanisasi. Partisipasi ide memberikan gagasan pipanisasi ini sangat membantu seluruh warga yang memanfaatkan pembangunan yang dilaksanakan oleh pemerintah desa.

Dorongan dari Kepala Desa Kuala Sempang dan aparatnya cukup berhasil menjalankan fungsi dan perannya dalam mendorong dan mengarahkan partisipasi 
masyarakat sehingga cukup berhasil dalam menyelesaikan proyek pembuatan pipanisasi ini sebagaimana yang diharapkan oleh masyarakat di Desa Kuala Sempang.

Berdasarkan hasil penelitian ada beberapa masukan dan saran dari kajian ini adalah peran Kepala Desa Kuala Sempang dan aparatnya untuk memperjuangkan aspirasi masyarakat Desa Kuala Sempang mencapai tujuan dari pembangunan itu sendiri yaitu mensejahterakan seluruh masyarakat desa terus diberdayakan dan jajarannya terus-menerus menjalin hubungan yang baik dengan seluruh elemen yang ada di Desa Kuala Sempang mulai dari tokoh-tokoh masyarakat dan masyarakat secara keseluruhan sehingga dalam pertemuanpertemuan yang pemerintah desa laksanakan muncul ide atau gagasan-gagasan yang lebih baik agar dapat dipertimbangkan dan dilaksanakan oleh pemerintah desa untuk terus membangun desa yang sejahtera.

\section{DAFTAR PUSTAKA}

Adi, Isbandi Rukminto. 2001. Pemberdayaan, Pengembangan Masyarakat, dan Intervensi Komunitas (Pengantar pada Pemikiran dan Pendekatan Praktis). Jakarta: Lembaga Penerbit Fakultas Ekonomi Universitas Indonesia.

2007. Perencanaan Partisipatoris Berbasis Aset Komunitas : Dari Pemikiran Menuju Penerapan. FISIP UI Press.Depok.

Adisasmita, Rahardjo. 2006. Pembangunan Pedesaan dan Perkotaan.Yogyakarta: Graha Ilmu.

Arief, Budiman. 2000. Teori Pembangunan Dunia Ketiga.Jakarta: Gramedia Pustaka Utama

Budiardjo, Miriam. 2008. Dasar-Dasar Ilmu Politik. Jakarta: Gramedia Pustaka Utama.

Hanif.Nurcholis. 2011. Pertumbuhan dan Penyelengaraan Pemerintahan Desa. Jakarta: Erlangga.

Kuncoro, Mudrajad, 2014. Otonomi dan Pembangunan Daerah, Jakarta: Erlangga.

Moleong, Lexy. 2010. Metode Penelitian Kualitatif Edisi Revisi. Bandung: Remaja Rosdakarya.

Nyoman, I Sumaryadi. 2005. Perencanaan Pembangunan Daerah Otonom Dan Pemberdayaan Masyarakat, Jakarta: Citra Utama.

Solekhan, Moch. 2012. Penyelenggaraan Pemerintahan Desa. Malang: Setara.

Sugiyono. 2005.Metode Penelitian Kualitatif. Bandung: Alfabeta. 
Supriatna, Tjahya. 2000.Strategi Pembangunan dan Kemiskinan. Jakarta: Rineka Cipta.

Syafiie, Inu Kencana. 2009. Pengantar Ilmu Pemerintahan. Bandung: Refika Aditama. . 2011. Etika Pemerintahan. Jakarta: Rineka Cipta.

Zubaedi, 2013.Pengembangan Masyarakat.Jakarta: Kencana Prenadamedia Group

Republik Indonesia, Undang-Undang Tentang Pemerintah Daerah Nomor 32 Tahun 2004.

Republik Indonesia, Undang-Undang Tentang Sistem Perencanaan Pembangunan Nasional Nomor 25 Tahun 2004.

Republik Indonesia, Undang-Undang Tentang Desa Nomor 6 Tahun 2014.

Republik Indonesia, Peraturan Pemerintah Tentang Desa Nomor 72 Tahun 2005.

RPJM-Desa Tahun 2011-2015 Desa Kuala Sempang Kecamatan Seri Kuala Lombam Kabupaten Bintan Provinsi Kepulauan Riau. 